\title{
Photo-fermentative bacteria aggregation triggered by L-cysteine during hydrogen production
}

\author{
Guo-Jun Xie, Bing-Feng Liu*, De-Feng Xing, Jun Nan, Jie Ding and Nan-Qi Ren*
}

\begin{abstract}
Background: Hydrogen recovered from organic wastes and solar energy by photo-fermentative bacteria (PFB) has been suggested as a promising bioenergy strategy. However, the use of PFB for hydrogen production generally suffers from a serious biomass washout from photobioreactor, due to poor flocculation of PFB. In the continuous operation, PFB cells cannot be efficiently separated from supernatant and rush out with effluent from reactor continuously, which increased the effluent turbidity, meanwhile led to increases in pollutants. Moreover, to replenish the biomass washout, substrate was continuously utilized for cell growth rather than hydrogen production. Consequently, the poor flocculability not only deteriorated the effluent quality, but also decreased the potential yield of hydrogen from substrate. Therefore, enhancing the flocculability of PFB is urgent necessary to further develop photo-fermentative process.

Results: Here, we demonstrated that L-cysteine could improve hydrogen production of Rhodopseudomonas faecalis RLD-53, and more importantly, simultaneously trigger remarkable aggregation of PFB. Experiments showed that L-cysteine greatly promoted the production of extracellular polymeric substances, especially secretion of protein containing more disulfide bonds, and help for enhancement stability of floc of PFB. Through formation of disulfide bonds, L-cysteine not only promoted production of EPS, in particular the secretion of protein, but also stabilized the final confirmation of protein in EPS. In addition, the cell surface elements and functional groups, especially surface charged groups, have also been changed by L-cysteine. Consequently, absolute zeta potential reached a minimum value at $1.0 \mathrm{~g} / \mathrm{l}$ of L-cysteine, which obviously decreased electrostatic repulsion interaction energy based on DLVO theory. Total interaction energy barrier decreased from $389.77 \mathrm{KT}$ at $0.0 \mathrm{~g} / \mathrm{l}$ of L-cysteine to $127.21 \mathrm{kT}$ at $1.0 \mathrm{~g} / \mathrm{l}$.

Conclusions: Thus, the strain RLD-53 overcame the total energy barrier and flocculated effectively. After a short settlement, the biomass rush out will be significantly reduced and the effluent quality will be greatly improved in the continuous operation. Furthermore, aggregation of PFB could enable high biomass hold-up of photobioreactor, which allows the photobioreactor to operate at low hydraulic retention time and high organic loading rate. Therefore, the described flocculation behaviour during photo-hydrogen production is potentially suitable for practicable application.
\end{abstract}

Keywords: Bioflocculation, Photo-hydrogen production, L-Cysteine, Extracellular polymeric substances, Disulfide bonds, DLVO

\footnotetext{
* Correspondence: Ibf@hit.edu.cn; bio-h2@hit.edu.cn

State Key Laboratory of Urban Water Resource and Environment, Harbin Institute of Technology, P.O. Box 261473 Huanghe Road, Harbin 150090, China
} 


\section{Background}

Global growing concerns about energy shortages and the environmental pollution have led to worldwide use of renewable energy. Hydrogen is considered as a viable energy carrier for the future which could play an important role in the reduction of emissions of greenhouse gases [1,2]. Recently, biological hydrogen production processes, especially photo-fermentative hydrogen production by PFB has been attracting more and more attention, as it utilizes various renewable sources like biomass and sunlight to produce an ideal, renewable and carbon-free energy for the future [3]. However, it should be realized that most of photo-fermentative processes are based on suspended culture [4-6] in which it is difficult to achieve high biomass concentration, effective retention and separation of PFB biomass, resulting from poor flocculation of PFB [7]. For steady-state operation of photobioreactor, due to the poor flocculability, PFB cells cannot be efficiently separated from supernatant and rush out with effluent from reactor continuously. This increased the effluent turbidity, meanwhile led to increases in pollutants like chemical oxygen demand, total nitrogen, and total phosphate, causing poor effluent water quality. Furthermore, to replenish the biomass washout, substrate was continuously utilized for cell growth rather than hydrogen production $[8,9]$. Thus, the poor flocculability not only deteriorated the effluent quality, but also decreased the potential yield of hydrogen from substrate. Therefore, enhancing the flocculability of PFB is urgent necessary to further develop photo-fermentative process.

Previous studies also tried to isolate self-flocculated PFB or enhance flocculation of PFB, but successful case was rare. Watanabe [10] first and only reported that photosynthetic bacteria Rhodovulum sp. PS88 has a selfflocculating activity. And high density cell culture was obtained under continuous cultivation in a single-tower fermenter [11]. However, there was no report about photo-hydrogen production and flocculation mechanism of Rhodovulum sp. PS88. According to the DLVO theory, the PFB, Rhodopseudomonas acidophila, could not overcome the total energy barrier to flocculate effectively, because contribution of van der Waals interaction energy to the total interaction energy could be neglected resulting from the small effective Hamaker constant $\left(2.27 \times 10^{-23} \mathrm{~J}\right)$ [12]. As a result, $R$. acidophila could not overcome the total energy barrier to flocculate effectively. So far, the information about PFB could flocculate and simultaneously improve hydrogen production have been not yet reported, and effective method and detailed mechanism of flocculation in photo-fermentation hydrogen production is still lacking.

In this work, we first time found that the L-cysteine induced the obvious bioflocculation of Rhodopseudomonas faecalis RLD-53 and at the same time promoted hydrogen production. Traditionally, flocculability of biological cells highly depended on the extracellular polymeric substances (EPS) [13], bacterial surface characteristics [14] and electrolyte concentration [15]. However, L-cysteine is unique natural amino acids containing a thiol group, which could form disulfide bond. Disulfide bonds are crucial to the folding and stability of many proteins [16,17], usually proteins secreted to the extracellular medium. As a predominant component in EPS, proteins have been demonstrated to play a crucial role in the bacterial aggregation $[18,19]$. Therefore, the mechanism of aggregation triggered by L-cysteine was explored through combination biological function of L-cysteine and traditional flocculation theory. EPS, surface properties and zeta potential of PFB were investigated for better understanding flocculation characteristics of strain RLD-53 under different concentration of L-cysteine. Effect of disulfide bonds on components of EPS production and conformational changes of proteins in EPS were also determined. Furthermore, contribution of specific EPS protein conformation and cell surface functional groups to bacterial aggregation were further discussed. Finally, the DLVO theory was used to evaluate the flocculability of $R$. faecalis RLD-53.

\section{Results and discussion}

\section{Hydrogen production and bioflocculation of}

\section{R. faecalis RLD-53}

Hydrogen productions were carried out at different Lcysteine concentrations $(0.5,1.0$ and $1.5 \mathrm{~g} / \mathrm{l})$ in batch culture and the control was no addition of L-cysteine. After cumulative hydrogen production was obtained, modified Gompertz equation was used as kinetic model to determine the hydrogen production kinetics of $R$. faecalis RLD53 at different L-cysteine concentrations (Figure 1). The hydrogen production kinetic parameters at different Lcysteine concentrations were shown in Table 1 . The maximum cumulative hydrogen production $\left(H_{\max }\right)$ and maximum production rate $\left(R_{\max }\right)$ increased with increasing L-cysteine concentration from 0.0 to $1.0 \mathrm{~g} / \mathrm{l}$, but decreased with further increasing the L-cysteine concentrations from 1.0 to $1.5 \mathrm{~g} \mathrm{l} / \mathrm{l}$. At $1.0 \mathrm{~g} / \mathrm{l}$ of L-cysteine, hydrogen production started rapidly with the lag phase of about $27.46 \mathrm{~h}$, reaching the maximum hydrogen yield of $2.58 \mathrm{~mol} \mathrm{H}_{2} / \mathrm{mol}$ acetate and production rate of $32.85 \mathrm{ml} /$ $\mathrm{l} / \mathrm{h}$, respectively. However, at $1.5 \mathrm{~g} / \mathrm{l}$ of L-cysteine, hydrogen production started slowly, did not reach the maximum rate of $20.81 \mathrm{ml} / \mathrm{l} / \mathrm{h}$ until lag time $46.10 \mathrm{~h}$ and hydrogen yield was only $1.66 \mathrm{~mol} \mathrm{H}_{2} / \mathrm{mol}$ acetate. The results indicated that a proper concentration of L-cysteine $(1.0 \mathrm{~g} / \mathrm{l})$ could promote the hydrogen production, while excessive L-cysteine depressed the hydrogen productivity.

In order to further demonstrate above results, acetylene reduction was used to determine the activity of nitrogenase, which catalysed the hydrogen production in 


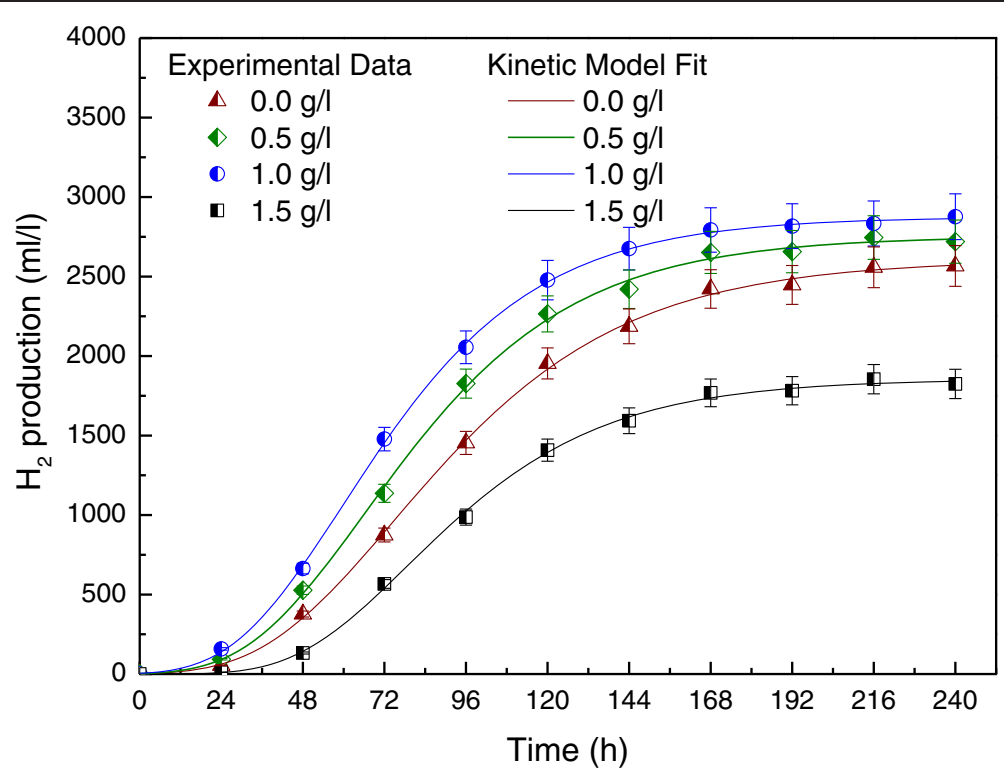

Figure 1 Hydrogen production kinetics of $R$. faecalis RLD-53 at different L-cysteine concentrations.

photofermentation [3]. As shown in Table 1, nitrogenase activities increased with the L-cysteine concentration, reached maximum $\left(1374 \mathrm{nmol} \mathrm{C}_{2} \mathrm{H}_{4} / \mathrm{ml} / \mathrm{h}\right)$ at $1.0 \mathrm{~g} / \mathrm{l}$. However, with further increase of L-cysteine to $1.5 \mathrm{~g} / \mathrm{l}$, the nitrogenase activity sharply decreased to765 $\mathrm{C}_{2} \mathrm{H}_{4} / \mathrm{ml} / \mathrm{h}$. Thiol group from L-cysteine is a key part of active sites in nitrogenase, which play an important role in structure and function of nitrogenase [20,21]. In chemical evolution of a nitrogenase model, the ratio of thiol and molybdenum significantly influenced the catalytic activity, and the maximum catalytic activity was obtained at ratio of 1:1 [22]. In this study, nitrogenase activity was enhanced by increasing of thiol from L-cysteine, but strongly depressed by excessive L-cysteine.

Figure 2 showed the cell growth and flocculability of $R$. faecalis RLD-53 at various L-cysteine concentrations. Cell biomass increased with the concentration of L-cysteine from 0 to $1.0 \mathrm{~g} / \mathrm{l}$, reached maximum $(1.08 \mathrm{~g} / \mathrm{l})$ at $1.0 \mathrm{~g} / \mathrm{l}$, and then decreased sharply with further increase of $\mathrm{L}$-cysteine to $1.5 \mathrm{~g} / \mathrm{l}$. The results suggested that excessive L-cysteine depressed cell growth of RLD-53. In the previous study, L-cysteine was also found to inhibit the growth of Neurospora crassa at high concentration, due to itself rather than its metabolism products [23]. The flocculability increased from 16.73 to $40.86 \%$ with an increase in L-cysteine concentration from 0.0 to $1.0 \mathrm{~g} / \mathrm{l}$, and then decreased. Above results indicated that suitable concentration of L-cysteine could significantly enhance the flocculability of $R$. faecalis RLD-53 and also promote photo-hydrogen production. After standing for 5 minutes, the absorbance of the supernatant decreased with increasing L-cysteine concentration. This suggested that after a short settlement, the biomass rush out could be significantly reduced and the effluent quality could be greatly improved in the continuous operation. Therefore, the described flocculation behaviour of $R$. faecalis RLD-53 during photo-hydrogen production is potentially suitable for practicable application.

As seen from Figure 3a, bioflocculation formation increased with the concentration of L-cysteine, and best floc was observed at $1.0 \mathrm{~g} / \mathrm{l}$. And then, bioflocculation decreased with L-cysteine, due to weak cell growth at high concentration of L-cysteine. The result showed that L-cysteine could cause the remarkable flocculation of R. faecalis RLD-53. After formation (about 48 hours), the floc was stable in whole hydrogen production, which

Table 1 Effect of L-cysteine concentration on hydrogen production kinetics and nitrogenase activity

\begin{tabular}{|c|c|c|c|c|c|c|}
\hline L-cysteine (g/l) & $\mathrm{H}_{2}$ yield ( $\mathrm{mol} \mathrm{H}_{2} / \mathrm{mol}$ acetate) & $H_{\max }(\mathrm{ml} / \mathrm{l})$ & $R_{\max }(\mathrm{ml} / \mathrm{l} / \mathrm{h})$ & $\lambda(\mathrm{h})$ & $r^{2}$ & Nitrogenase activity $\left(\mathrm{nmol} \mathrm{C}_{2} \mathrm{H}_{4} / \mathrm{ml} / \mathrm{h}\right)$ \\
\hline 0.0 & $2.33 \pm 0.106$ & $2610 \pm 118$ & 24.97 & 36.22 & 0.998 & $957 \pm 85$ \\
\hline 0.5 & $2.46 \pm 0.123$ & $2755 \pm 137$ & 29.35 & 31.77 & 0.997 & $1125 \pm 78$ \\
\hline 1.0 & $2.58 \pm 0.129$ & $2878 \pm 144$ & 32.85 & 27.46 & 0.994 & $1374 \pm 94$ \\
\hline 1.5 & $1.66 \pm 0.114$ & $1859 \pm 127$ & 20.81 & 46.10 & 0.996 & $765 \pm 69$ \\
\hline
\end{tabular}




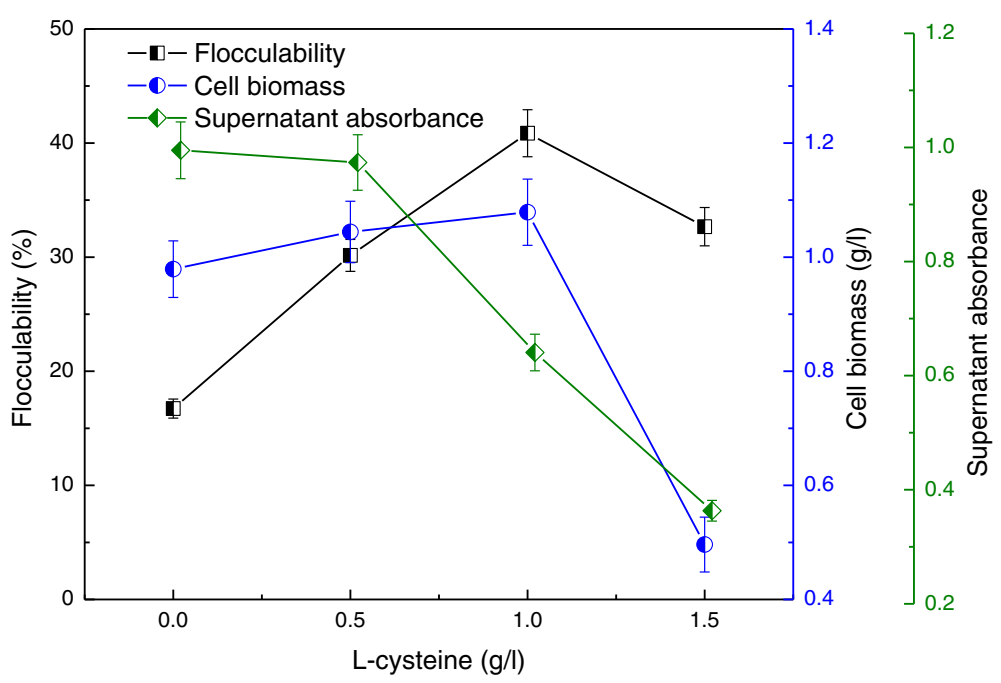

Figure 2 Cell growth and flocculability of $R$. faecalis RLD-53 at different L-cysteine concentrations.

indicated that flocculation of $R$. faecalis RLD-53 could be applied in the continuous hydrogen production. Scanning electron microscope (SEM) analysis also showed that there were clear morphological differences of bioflocculation at different concentration of L-cysteine (Figure 3b). Loosely structure was observed in the control ( $0 \mathrm{~g} / \mathrm{l}$ of L-cysteine) and there were almost not formation of floc. Interaction adhesion among cells increased and formed a stable structure through covered and tightly linked together by EPS at $1.0 \mathrm{~g} / \mathrm{l}$ of L-cysteine. The amount of EPS on the cell surface was increased with the $\mathrm{L}$-cysteine from 0.0 to $1.0 \mathrm{~g} / \mathrm{l}$, indicating that proper concentration of L-cysteine may promote the production of EPS. The porous structure of the floc was also observed at

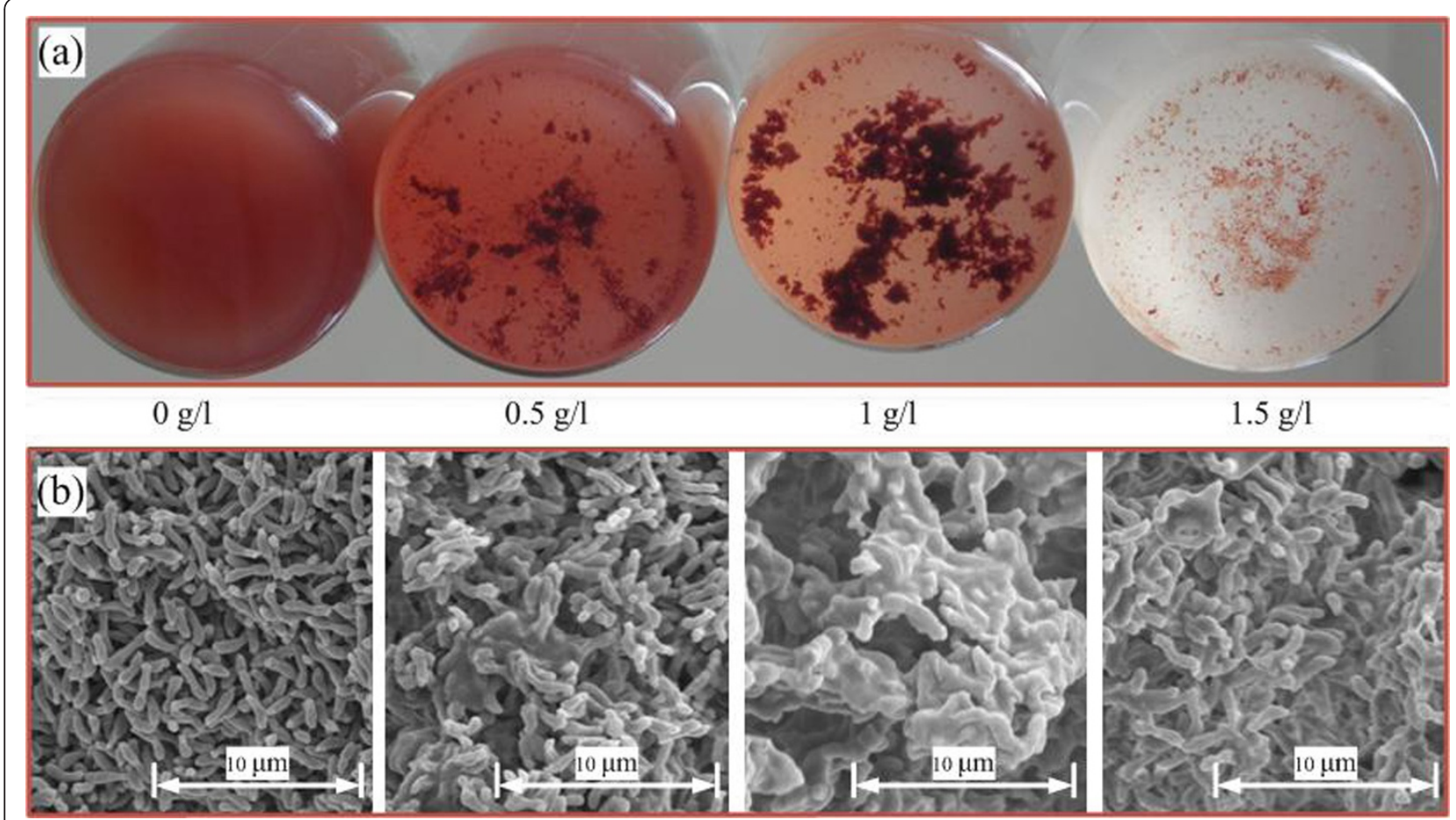

Figure 3 Bioflocculation of $R$. faecalis RLD-53 at different concentration of L-cysteine. (a) photo of bioflocculation; (b) SEM images of bioflocculation. 
$1.0 \mathrm{~g} / \mathrm{l}$. Such structure was likely to facilitate the passage of substrate and the release of hydrogen gas as well as light penetration.

\section{EPS of $R$. faecalis RLD-53}

EPS have been reported as a major component in microbial aggregates and play a crucial role in bioflocculation formation [24]. Characteristics and the contents of the EPS have significant effect on the formations and properties of microbial aggregates [13]. Figure 4 illustrated the effect of L-cysteine concentrations on EPS chemical compositions. The total EPS content increased from 24.23 to $60.47 \mathrm{mg} / \mathrm{g}$ dry cell with the increase of L-cysteine from 0 to $1.0 \mathrm{~g} / \mathrm{l}$. A further increase in L-cysteine concentrations decreased of EPS content, due to inhibition from excessive L-cysteine. The polysaccharides, proteins and humic substances were the major component of EPS from strain RLD-53. Compared with the control $(0 \mathrm{~g} / \mathrm{l})$, the EPS at 1.0 $\mathrm{g} / \mathrm{l}$ of L-cysteine increased by $36.24 \mathrm{mg} / \mathrm{g}$ dry cell, mainly $(18.03 \mathrm{mg} / \mathrm{g})$ from increase of protein secretion. Previous studies reported that with high content of negatively charged amino acids, protein is more interacted than polysaccharides with multivalent cations for stabilizing floc structure [18]. Removal of proteins from the sludge floc resulted in deflocculation, which demonstrated the important function of protein in formation of floc [19]. These results indicated that L-cysteine promoted the production of extracellular polymeric substances, especially protein secretion, which facilitated bioflocculation formation.

In addition, humic substances also increased significantly (Figure 4). Humic substances are a natural organic matter, resulting from the biodegradation of dead biomass, which are resistant to degradation [25]. In the pure culture of photofermentative bacteria, humic substances mainly came from the dead cell decomposition. In free cell culture, cell debris and humic substances from the dead cell decomposition may disperse into the culture broth. However, after the bioflocculation formation, humic substances from dead cell decomposition may be retained in the EPS matrix. As a result, the humic substances also significantly increase, due to the floc formation caused by L-cysteine.

Disulfide bonds formation from L-cysteine are crucial to the folding and stability of many proteins $[16,17]$, usually proteins secreted to the extracellular medium. Figure $4 \mathrm{~b}$ presented disulfide bonds concentrations in the EPS at different L-cysteine concentration. The disulfide bonds content in EPS increased with the increase of L-cysteine concentration, and reached maximum at $1.0 \mathrm{~g} / \mathrm{l}$ of L-cysteine (Figure $4 \mathrm{~b}$ ), corresponding to the above mentioned maximum proteins production in EPS (Figure 4a). Disulfide bonds detected in the control may come from the inoculation containing a small amount of L-cysteine. The relationships between disulfide bonds and components of EPS production were also investigated, as shown in Figure 5. Compared with other components of EPS, proteins had the most significant positive linear relationship with disulfide bonds based on correlation coefficients $\left(R^{2}=0.924\right)$ (Figure 5$)$. In the previous studies, bovine pancreatic trypsin inhibitor (a model protein to investigate protein structure and folding pathways) secretion efficiency was significantly decreased by disulfide removal [26], while proteins secretion in Pichia pastoris were enhanced by overexpression of protein disulfide isomerase, which helped in rearrangement of incorrect disulfide pairings [27]. Therefore, our results implied that the formation of disulfide bonds from L-cysteine stimulated the secretions of proteins and it is beneficial to stabilize floc.
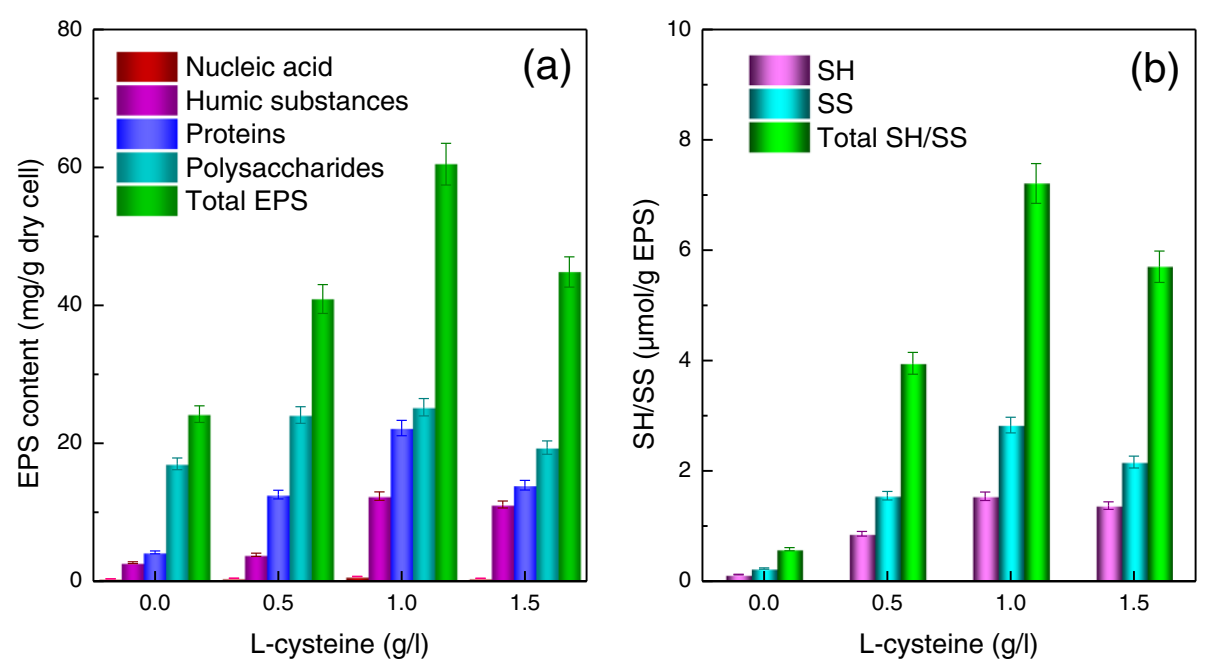

Figure 4 EPS compositions of $R$. faecalis RLD-53 at various concentration of L-cysteine. (a), EPS component; (b), thiol group (SH) and disulfide bond (SS) content in EPS. 

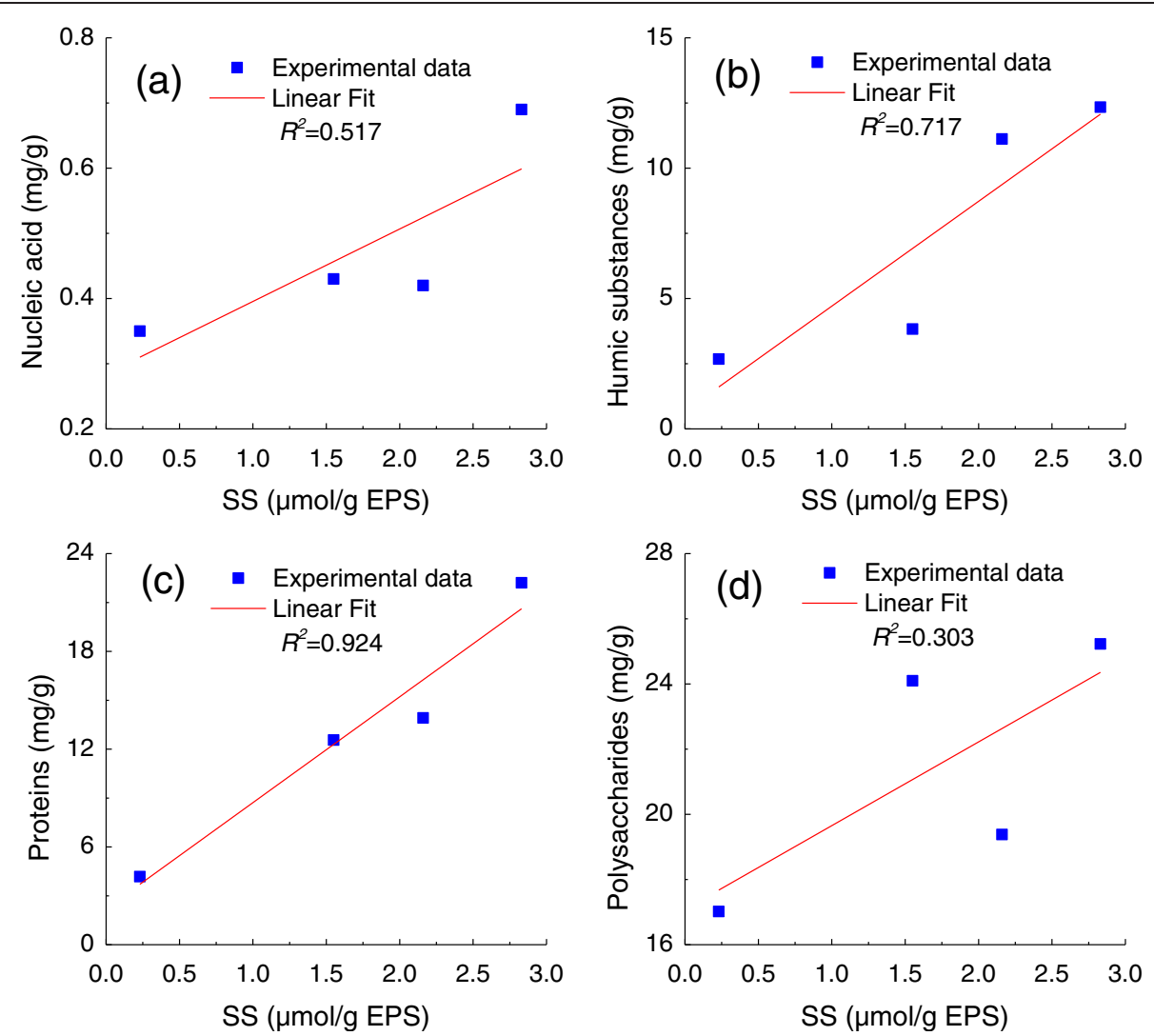

Figure 5 Relationship between disulfide bonds and components of EPS production. (a), Nucleic acid; (b), Humic substances; (c), Proteins; (d), Polysaccharides.

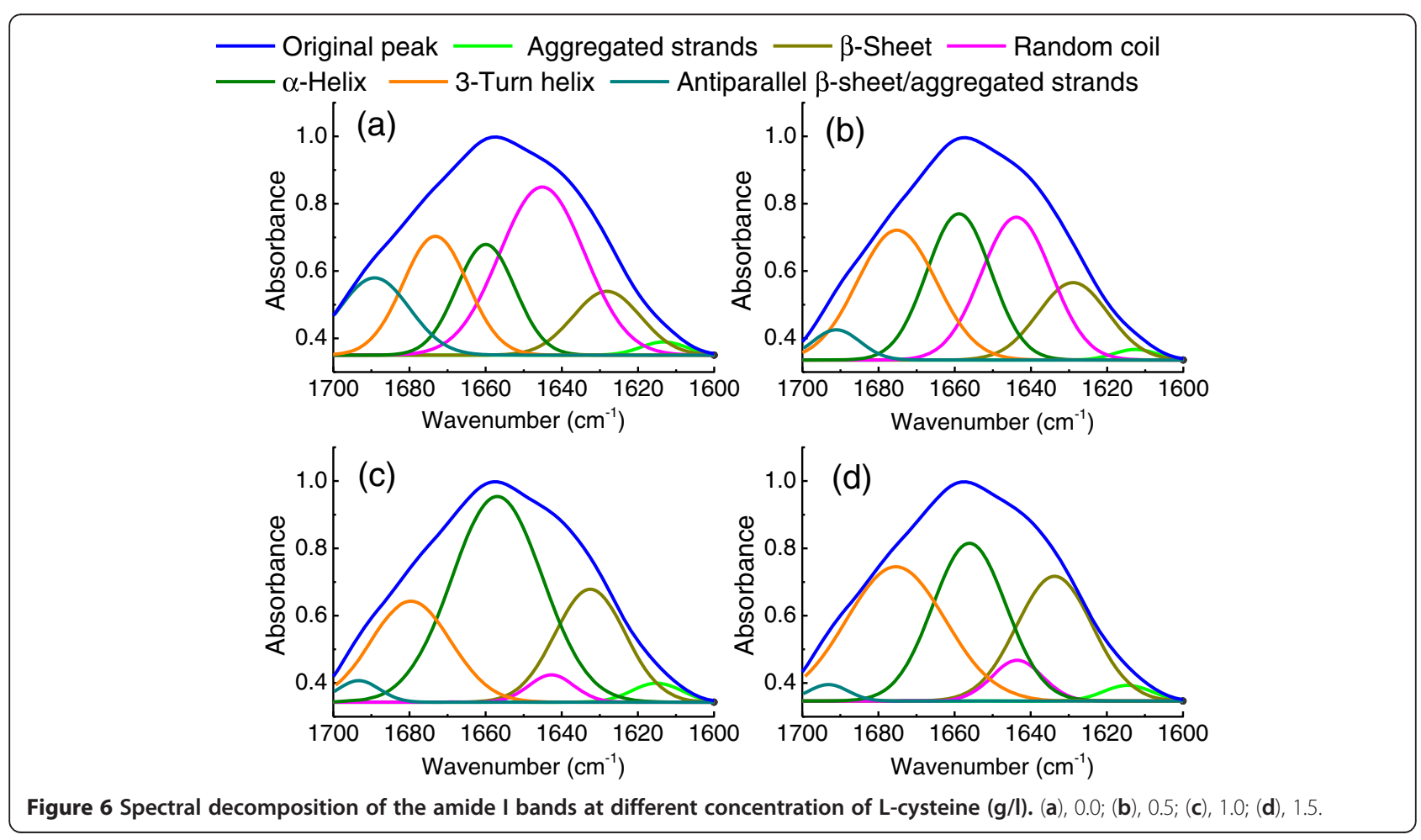


In addition, the biological function of disulfide bonds includes stabilization of protein structure as well as determining the pathway and efficiency of protein folding $[28,29]$. Thus, the potential impacts of L-cysteine on the conformations of EPS proteins were further explored based on amide I region $\left(1600-1700 \mathrm{~cm}^{-1}\right)$ in the Fourier Transform Infrared Spectroscopy (FTIR) spectra [30] (Figure 6). The percentages of secondary structure were determined from the areas of the individual assigned bands and their fraction of the total area in the amide I (Table 2$)$. In the control $(0 \mathrm{~g} / \mathrm{l})$, random coil was predominant in EPS proteins, while 3-Turn helix, $\alpha$-Helix, $\beta$-Sheet and antiparallel $\beta$-sheet/aggregated strands also had considerable proportion. With the increasing of L-cysteine, the content of random coil and antiparallel $\beta$-sheet/aggregated strands significantly decreased, while $\alpha$-Helix and $\beta$ Sheet increased. These results indicated that the protein conformations were greatly changed by disulfide bonds from L-cysteine.

Conformation of protein could be influenced by contact time with the matrix [31], hydrophobicity of surface [32] and curvature of matrix [33]. Such changes of protein molecules on bacterial surface were not reversible. So, the conformational changes of proteins were suggested as driving force for bacterial adhesion to solid matrix [34]. In this study, the contribution of specific conformation of EPS protein to flocculability of PFB were further analysed in Figure 7. Aggregated strands, $\beta$-sheets and $\alpha$-helices promoted bioflocculation formation (Figure $6 a, b$ and $d$ ), but random coils and antiparallel $\beta$-sheet/aggregated strands deteriorated flocculability (Figure $6 \mathrm{c}$ and $\mathrm{f}$ ). However, there was no obvious corresponding relationship between 3-Turn helix and flocculability (Figure 6e).

\section{Cell surface functional groups of $R$. faecalis RLD-53}

With increasing protein and EPS covering on the cell surface, the surface elemental composition and functional groups could be greatly influenced by L-cysteine. The surface elements and functional groups of $R$. faecalis RLD-53 were studied by X-ray photoelectron spectroscopy (XPS) (Additional file 1: Figure S1), which detected the outermost molecular layers (mainly EPS) of the cell surface (2-5 nm). The major peaks in the spectra identified by XPS were the $\mathrm{C} 1 \mathrm{~s}$ and $\mathrm{O} 1 \mathrm{~s}$, and $\mathrm{N}$ 1s peak, with minor peaks of $\mathrm{P}, \mathrm{Na}$, $\mathrm{Cl}$ and $\mathrm{Si}$. The functional groups on the cell surfaces were illustrated by high-resolution XPS spectra of the $\mathrm{C} 1 \mathrm{~s}, \mathrm{O} 1 \mathrm{~s}$ and $\mathrm{N}$ 1s region in Additional file 2: Figure S2. The $\mathrm{C} 1 \mathrm{~s}$ spectra were resolved into four individual component groups: $\mathrm{C}_{\mathrm{G} 1}, 284.6 \mathrm{ev}, \underline{\mathrm{C}}-(\mathrm{C}, \mathrm{H})$ mainly from hydrocarbons; $\mathrm{C}_{\mathrm{G} 2}, 286.2 \mathrm{eV}, \underline{\mathrm{C}}-(\mathrm{O}, \mathrm{N})$ from proteins and alcohols; $\mathrm{C}_{\mathrm{G} 3}$, $287.8 \mathrm{eV}, \underline{\mathrm{C}}=\mathrm{O}$ or $\mathrm{O}-\underline{\mathrm{C}}-\mathrm{O}$ from carboxylate, carbonyl, amide, acetals, or hemiacetals, and $\mathrm{C}_{\mathrm{G} 4}, 289.2 \mathrm{eV}, \mathrm{O}=\underline{\mathrm{C}}-\mathrm{OH}$ and $\mathrm{O}=\mathrm{C}-\mathrm{OR}$ commonly from uronic acids. The $\mathrm{O} 1 \mathrm{~s}$ peak was decomposed into two peaks, $\mathrm{O}_{\mathrm{G} 1}, 531.3 \mathrm{eV}, \underline{\mathrm{O}}=\mathrm{C}$ from carboxylate, carbonyl, ester, or amide, and $\mathrm{O}_{\mathrm{G} 2}, 532.7 \mathrm{eV}$, $\mathrm{O}-(\mathrm{C}, \mathrm{H})$ from hydroxide, acetal, and hemiacetal. The $\mathrm{N} 1 \mathrm{~s}$ peak was also resolved into two component peaks, $\mathrm{N}_{\mathrm{G} 1}$, $399.9 \mathrm{eV}, \mathrm{O}=\mathrm{C}-\mathrm{NH}-\mathrm{R}$ from amines and amides, and $\mathrm{N}_{\mathrm{G} 2}$, $401.3 \mathrm{eV}, \mathrm{C}-\mathrm{NH}_{2}$ mainly from basic amino acids. The percentages of surface functional groups were determined from the XPS peaks area after subtraction of a linear background (Table 2). The results showed that the functional groups on the cell surface of $R$. faecalis RLD-53 were significantly affected by L-cysteine concentration.

The contribution of cell surface functional groups to flocculability of PFB was presented in Figure 8. Result showed that the present of $\underline{\mathrm{C}}-(\mathrm{O}, \mathrm{N})$ and $\underline{\mathrm{C}}=\mathrm{O}$ or $\mathrm{O}-\underline{\mathrm{C}}-\mathrm{O}$ on the cell surface promoted photo-fermentative bacteria flocculation, while compounds with $\underline{\mathrm{C}}-(\mathrm{C}, \mathrm{H})$ and $\mathrm{O}=\underline{\mathrm{C}}-$ $\mathrm{OH}, \mathrm{O}=\mathrm{C}-\mathrm{OR}$ on the cell surface deteriorated the flocculability (Figure 8a-d). The flocculability of $R$. faecalis RLD-53 and content of $\mathrm{O}-(\mathrm{C}, \mathrm{H})$ followed the same trends changed with concentration of L-cysteine, but no significant linear correlation (Figure $8 \mathrm{e}$ and $\mathrm{f}$ ). In addition, the $\mathrm{C}-\mathrm{NH}_{2}$ on the cell surface promoted bioflocculation whereas the $\mathrm{O}=\mathrm{C}-\mathrm{NH}-\mathrm{R}$ decreased bioflocculation ability (Figure $8 \mathrm{~g}$ and $\mathrm{h}$ ). Previously, some reports suggested that $\mathrm{O}=\mathrm{C}-\mathrm{OH}$ groups play an important role in flocculation [35], but others emphasized the importance of $\mathrm{C}-\mathrm{NH}_{2}$ [36]. In this work, the presence of $\mathrm{C}-\mathrm{NH}_{2}$ promoted microorganism flocculation whereas $\mathrm{O}=\mathrm{C}-\mathrm{OH}, \mathrm{O}=\mathrm{C}-\mathrm{OR}$ hampered bioflocculation (Figure $8 \mathrm{e}$ and $\mathrm{f}$ ). Therefore, the change of cell surface functional

Table 2 Conformation changes of EPS proteins from $R$. faecalis RLD-53 at different concentration of L-cysteine

\begin{tabular}{|c|c|c|c|c|c|}
\hline \multirow[t]{2}{*}{ Secondary structures } & \multirow{2}{*}{$\begin{array}{l}\text { Wavenumber } \\
\qquad\left(\mathrm{cm}^{-1}\right)\end{array}$} & \multicolumn{4}{|c|}{ L-cysteine (g/l) } \\
\hline & & 0.0 & 0.5 & 1.0 & 1.5 \\
\hline Aggregated strands (\%) & $1625-1610$ & 1.55 & 1.21 & 2.51 & 2.01 \\
\hline$\beta$-Sheet (\%) & $1640-1630$ & 11.33 & 14.73 & 21.09 & 25.31 \\
\hline Random coil (\%) & $1645-1640$ & 37.50 & 27.30 & 3.28 & 5.52 \\
\hline a-Helix (\%) & $1657-1648$ & 16.96 & 25.52 & 49.40 & 31.03 \\
\hline 3-Turn helix (\%) & $1666-1659$ & 20.13 & 27.63 & 21.35 & 34.54 \\
\hline Antiparallel $\beta$-sheet/ aggregated strands (\%) & $1680-1695$ & 12.53 & 3.62 & 2.38 & 1.59 \\
\hline
\end{tabular}




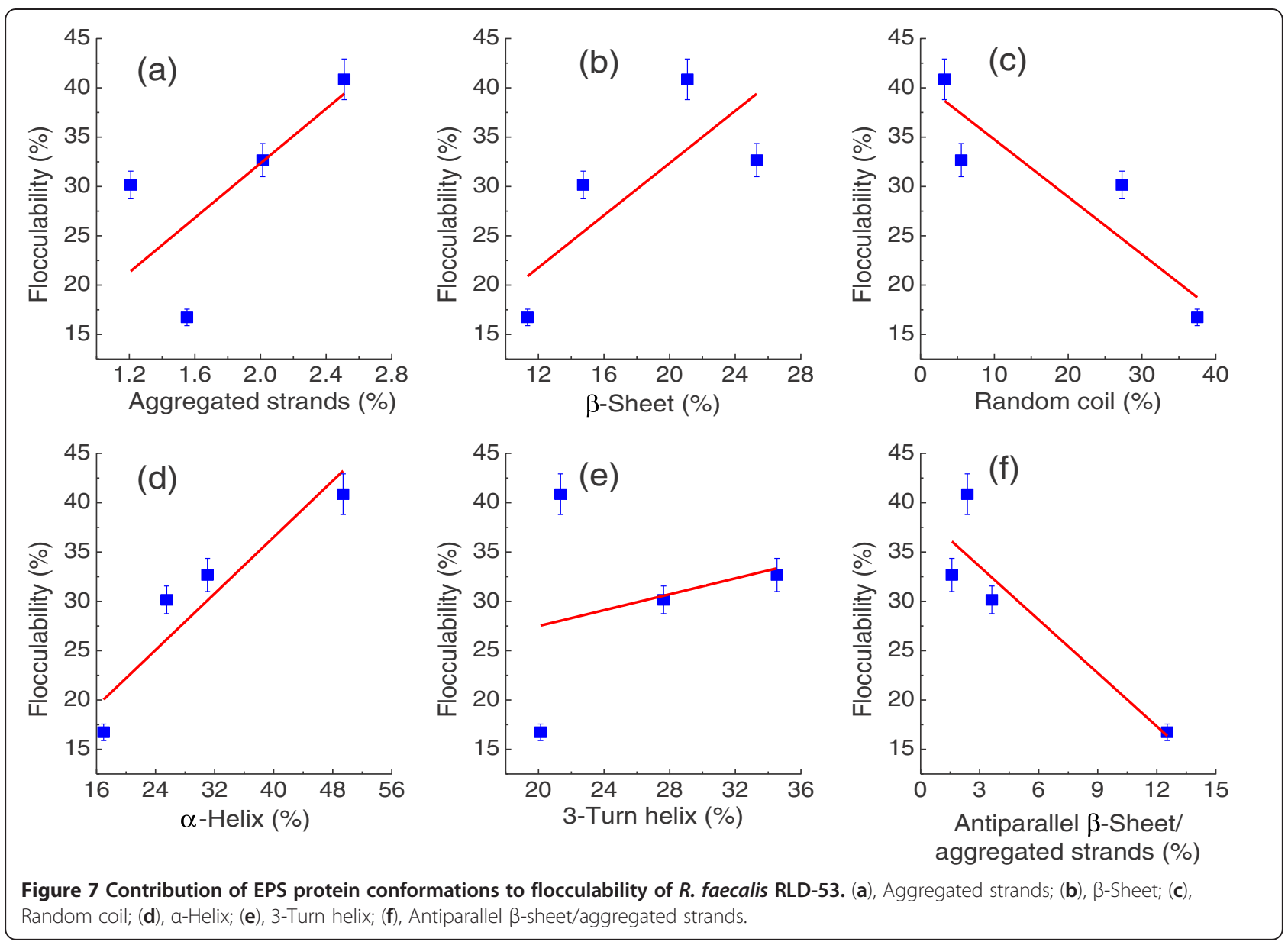

groups caused by L-cysteine was conducive to flocculation of PFB.

\section{Zeta potential of $R$. faecalis RLD-53}

Zeta potential is also an important parameter which characterizes the physicochemical properties of the bacterial cell envelope and plays an important role in aggregation and disaggregation processes [37]. The absolute zeta potential decreased with the L-cysteine concentration, and reached minimum at $1.0 \mathrm{~g} / \mathrm{l}$ (Additional file 3: Figure S3). This was mainly attributable to the changes in cell surface characteristics, especially changes in the functional groups caused by L-cysteine. Bacterial surface charge mainly originated from ionization of surface groups [38], including negatively charged (e.g., carboxyl, phosphoryl or sulfhydryl groups of carbohydrates and proteins) and positively charged groups (amine groups of amino acids, amino sugars) [37]. In this study, cell surface of $R$. faecalis RLD-53 mainly contained $\mathrm{COOH}$ and $\mathrm{C}-\mathrm{NH}_{2}$ as charged groups (Table 3). With increasing of $\mathrm{COOH}, \mathrm{COOR}$ content, the absolute zeta potential increased, due to the negative contribution to cell surface charge from ionization of $\mathrm{COOH}$ group (Figure 9). On the contrary, absolute zeta potential decreased with the content of $\mathrm{C}-\mathrm{NH}_{2}$ group, because negative net surface charge decreased by positive charge from ionization of $\mathrm{NH}_{2}$ group.

\section{Flocculability evaluated by DLVO theory}

DLVO theory has been widely applied as both qualitative and quantitative models to explain microbial adhesion and aggregation $[39,40]$. Here, DLVO theory was applied to predict the potential energy barrier that hindered aggregation of $R$. faecalis RLD-53 at different concentration of L-cysteine.

Application of the DLVO approach requires the surface thermodynamic parameters. Surface thermodynamic properties of $R$. faecalis RLD-53 cell were calculated through the measurement of the contact angles with of three different liquids (water, formamide, and 1-bromonaphthalene) (Figure 10). Cell surface hydrophobicity was determined by water contact angle $\theta_{W}$. Traditionally, surfaces are divided into two categories: wetting $\left(\theta_{W}<90^{\circ}\right)$ and non-wetting $\left(\theta_{W}>90^{\circ}\right)$. It is worth noting that hydrophobic interactions between surfaces become effective at $\theta_{W}>$ $65^{\circ}$ and hydrophilic interactions at $\theta_{W}<65^{\circ}$ [41]. In this study, the all of water contact angles $\left(\theta_{W}<65^{\circ}\right)$ indicated that cell surface was hydrophilic and hydrophilic 


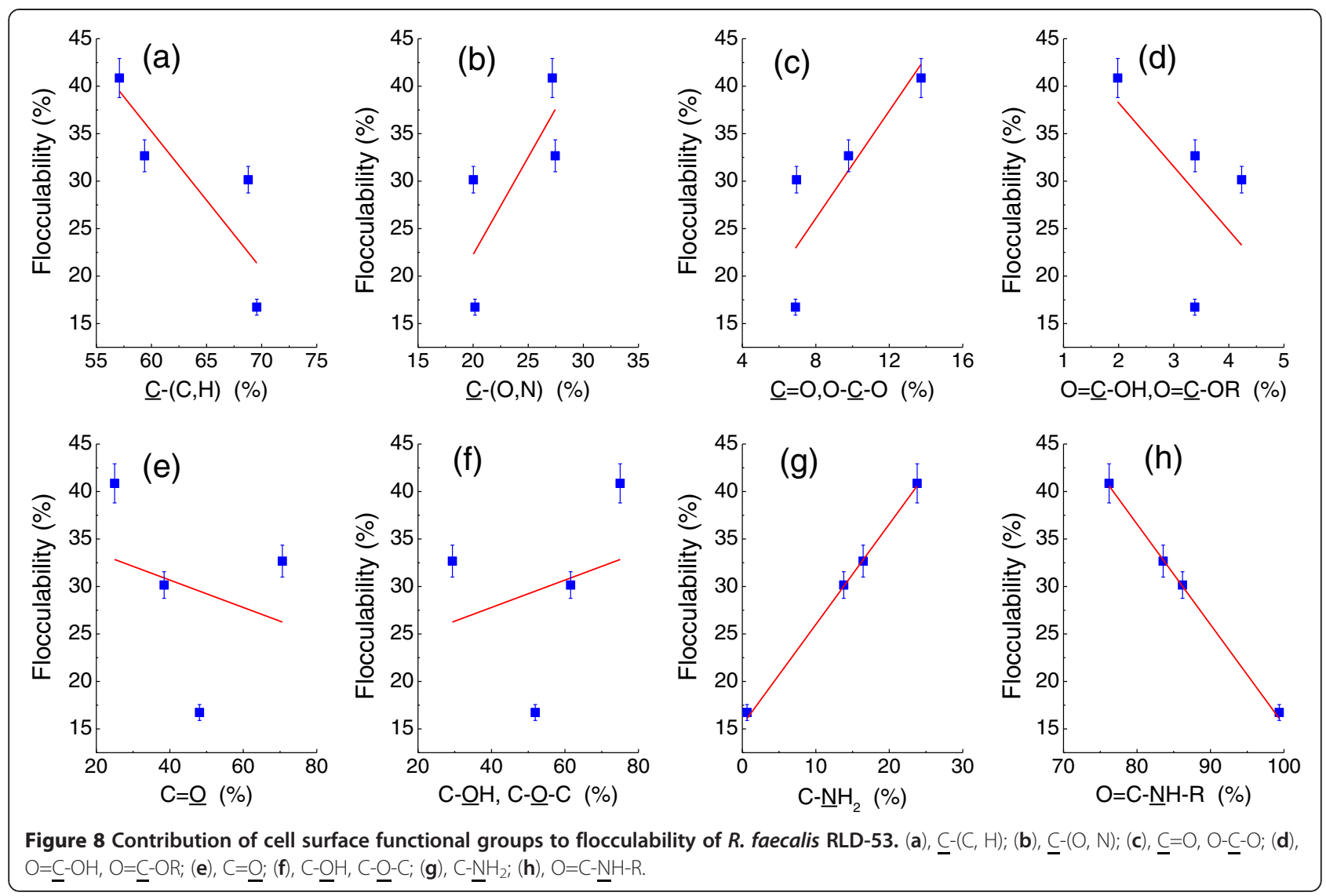

interactions were effective between cells of $R$. faecalis RLD-53. Hydrophilic interaction is the proclivity of strongly polar chains, molecules or particles for repelling each other in aqueous [41]. The hydrophilic interactions decreased with increasing the water contact angle resulting from different L-cysteine concentrations. This was favourable for the formation of biofloc.

The total interaction energies between the microbial cells were calculated as a function of the separation distance between the cell and cell in $0.01 \mathrm{~mol} / \mathrm{l} \mathrm{NaCl}$ (Figure 11). In the control, interaction energy barrier was 389.77 KT. The high energy barrier indicated stable cell suspension, corresponding to poor flocculability of $R$. faecalis RLD-53 at $0.0 \mathrm{~g} / \mathrm{l}$ of L-cysteine (Figure 2). The energy barrier dropped from 389.77 to $127.21 \mathrm{kT}$ with an increase in L-cysteine concentration to $1.0 \mathrm{~g} / \mathrm{l}$. Hence, the flocculability of $R$. faecalis RLD-53 increased with the increasing L-cysteine concentration (Figure 2). However, when the L-cysteine concentration was further increased to $1.5 \mathrm{~g} / \mathrm{l}$, bacterial cell growth and EPS production were depressed, resulting in increase of zeta potential and electrostatic repulsion $\left(W_{E L}\right)$. Consequently, the interaction energy barrier rebounded to $193.21 \mathrm{KT}$. Therefore, the flocculability of $R$. faecalis RLD-53 decreased at $1.5 \mathrm{~g} / \mathrm{l}$ of L- cysteine.

The poor flocculability of photosynthetic $\mathrm{H}_{2}$-producing bacterium, $R$. acidophila, was attributed to its inherent surface characteristics [12]. The effective Hamaker constant

Table 3 Results of the high-resolution XPS analysis of the $\mathrm{C} 1 \mathrm{~s}, \mathrm{O} 1 \mathrm{~s}$ and $\mathrm{N} 1 \mathrm{~s}$ peak region from cell surface

\begin{tabular}{|c|c|c|c|c|c|c|c|c|}
\hline \multirow{2}{*}{$\begin{array}{c}\text { L- } \\
\text { cysteine } \\
\text { (g/l) }\end{array}$} & \multicolumn{4}{|c|}{ C 1s (\%) } & \multicolumn{2}{|c|}{ O 1s (\%) } & \multicolumn{2}{|c|}{ N 1s (\%) } \\
\hline & $\begin{array}{c}\mathrm{C}_{\mathrm{G} 1} 284.8 \mathrm{eV} \\
\underline{\mathrm{C}}-(\mathrm{C}, \mathrm{H})\end{array}$ & $\begin{array}{c}\mathrm{C}_{\mathrm{G} 2} 286.2 \mathrm{eV} \\
\underline{\mathrm{C}-(\mathrm{O}, \mathrm{N})}\end{array}$ & $\begin{array}{l}\mathrm{C}_{\mathrm{G} 3} 287.8 \mathrm{eV} \\
\underline{C}=0,0-\underline{-}-\mathrm{O}\end{array}$ & $\begin{array}{c}\mathrm{C}_{\mathrm{G} 4} 289.2 \mathrm{eV} \\
\mathrm{O}=\underline{\mathrm{C}}-\mathrm{OH}, \mathrm{O}=\underline{\mathrm{C}}-\mathrm{OR}\end{array}$ & $\begin{array}{c}\mathrm{O}_{\mathrm{G} 1} 531.3 \mathrm{eV} \\
\mathrm{C}=\underline{\underline{0}}\end{array}$ & $\begin{array}{l}\mathrm{O}_{\mathrm{G} 2} 532.7 \mathrm{eV} \\
\mathrm{C}-\underline{\mathrm{OH}}, \mathrm{C}-\underline{\mathrm{O}}-\mathrm{C}\end{array}$ & $\begin{array}{c}\mathrm{N}_{\mathrm{G} 1} 399.1 \mathrm{eV} \\
\mathrm{O}=\mathrm{C}-\underline{\mathrm{NH}}-\mathrm{R}\end{array}$ & $\begin{array}{c}\mathrm{N}_{\mathrm{G} 2} 400.05 \mathrm{eV} \\
\mathrm{C}-\underline{\mathrm{NH}}_{2}\end{array}$ \\
\hline 0.0 & 69.55 & 20.17 & 6.89 & 3.38 & 48.09 & 51.91 & 99.36 & 0.64 \\
\hline 0.5 & 68.79 & 20.03 & 6.95 & 4.23 & 38.47 & 61.53 & 86.19 & 13.81 \\
\hline 1.0 & 57.10 & 27.18 & 13.73 & 1.98 & 24.98 & 75.02 & 76.20 & 23.80 \\
\hline 1.5 & 59.38 & 27.45 & 9.78 & 3.39 & 70.64 & 29.36 & 83.57 & 16.43 \\
\hline
\end{tabular}



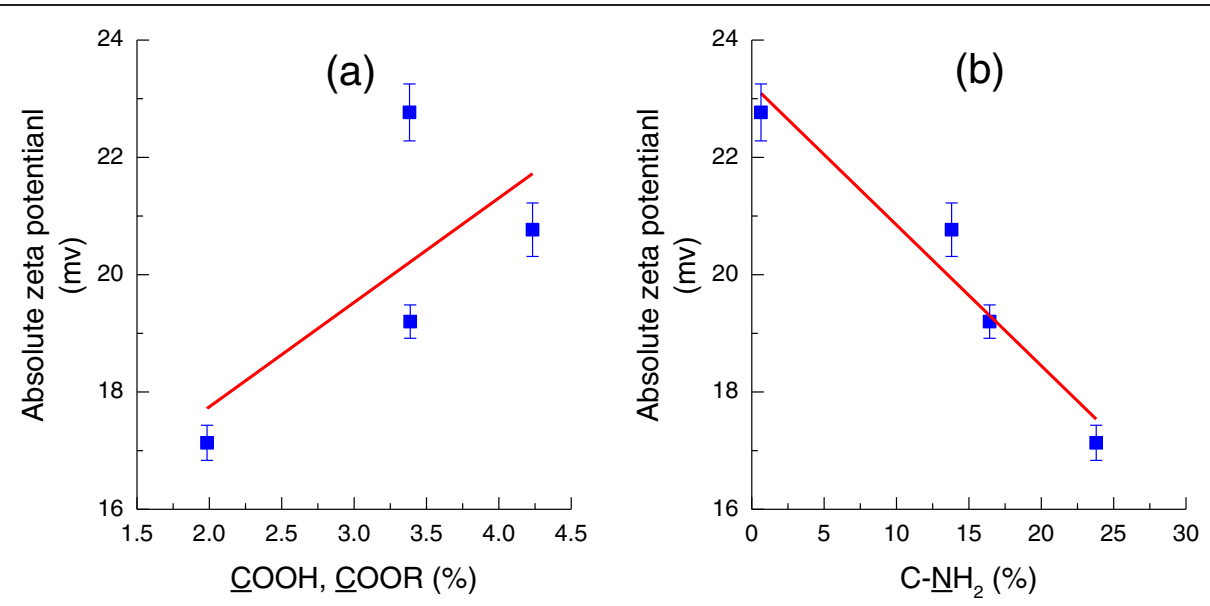

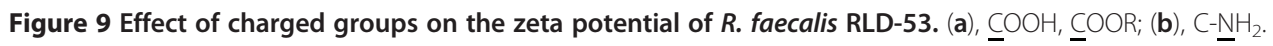

between $R$. acidophila and water was only $2.27 \times 10^{-23} \mathrm{~J}$, resulting in the negligible contribution of van der Waals interaction energy $\left(W_{L W}\right)$ to the total interaction energy. As a result, the interaction energy barrier between cells was up to $1665 \mathrm{KT}$ in $0.01 \mathrm{~mol} / \mathrm{l} \mathrm{NaCl}$ solutions. Consequently, the bacterial cells could not overcome the total energy barrier to flocculate effectively. In this study, the effective Hamaker constant between $R$. faecalis RLD-53 and water was $5.54 \times 10^{-21} \mathrm{~J}$ at $1.0 \mathrm{~g} / \mathrm{l}$ of L-cysteine, suggesting that van der Waals interaction energy was important for total interaction energy. In addition, the electrostatic repulsive energy $\left(W_{E L}\right)$ decreased with decreasing of absolute zeta potential, resulting from changes of surface charged groups caused by
L-cysteine. The interaction energy barrier between cells of $R$. faecalis RLD-53 was $127.21 \mathrm{KT}$. Therefore, $R$. faecalis RLD-53 flocculate effectively at $1.0 \mathrm{~g} / \mathrm{l}$ of L-cysteine.

\section{Conclusions}

In this work, L-cysteine was found to promote the effective flocculation and photo-hydrogen production of $R$, faecalis RLD-53. This finding suggested L-cysteine can be applied as flocculant for continuous photo-hydrogen production. Results showed that proper L-cysteine concentration $(1 \mathrm{~g} / \mathrm{l})$ improved flocculability and hydrogen productivity of $R$. faecalis RLD-53. The reasons of flocculation also were analysed. Through formation of disulfide bonds, L-cysteine
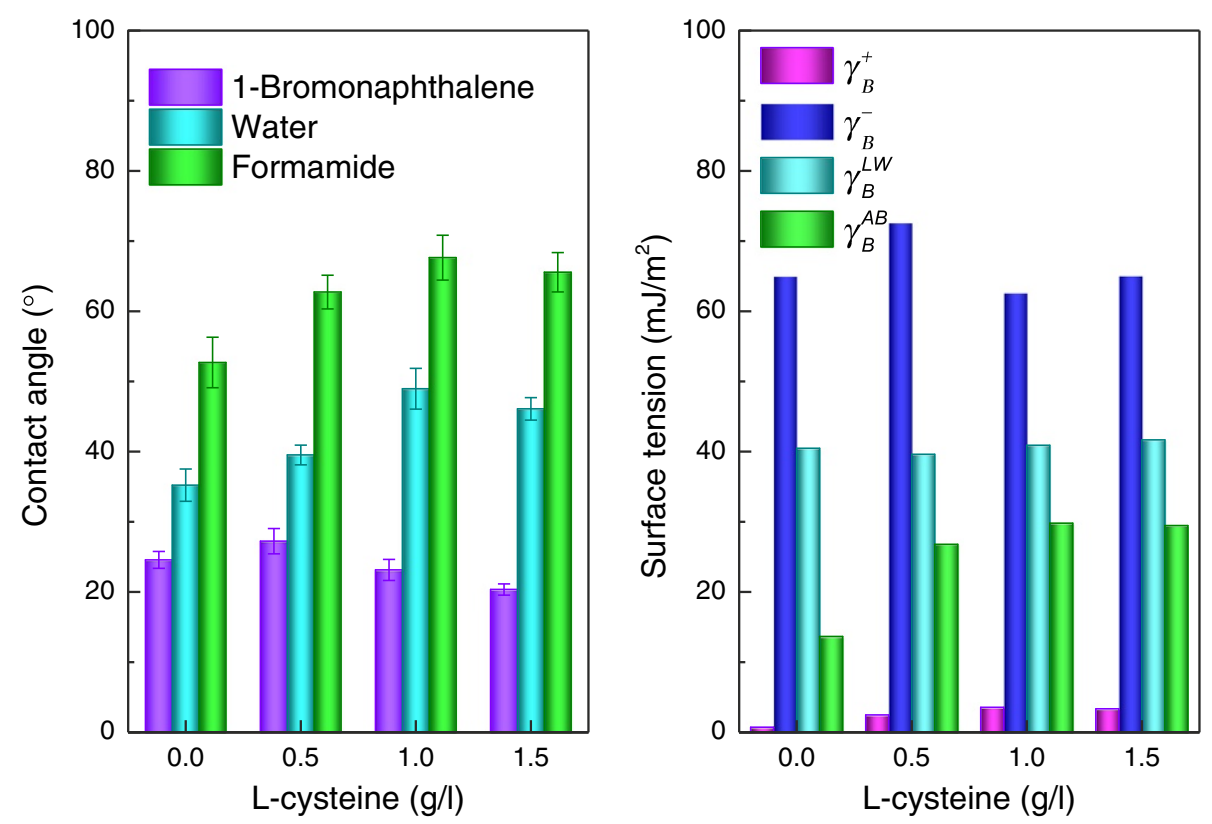

Figure 10 Contact angle and surface thermodynamic properties of $R$. faecalis RLD-53. (a), Contact angle; (b), surface thermodynamic properties. 

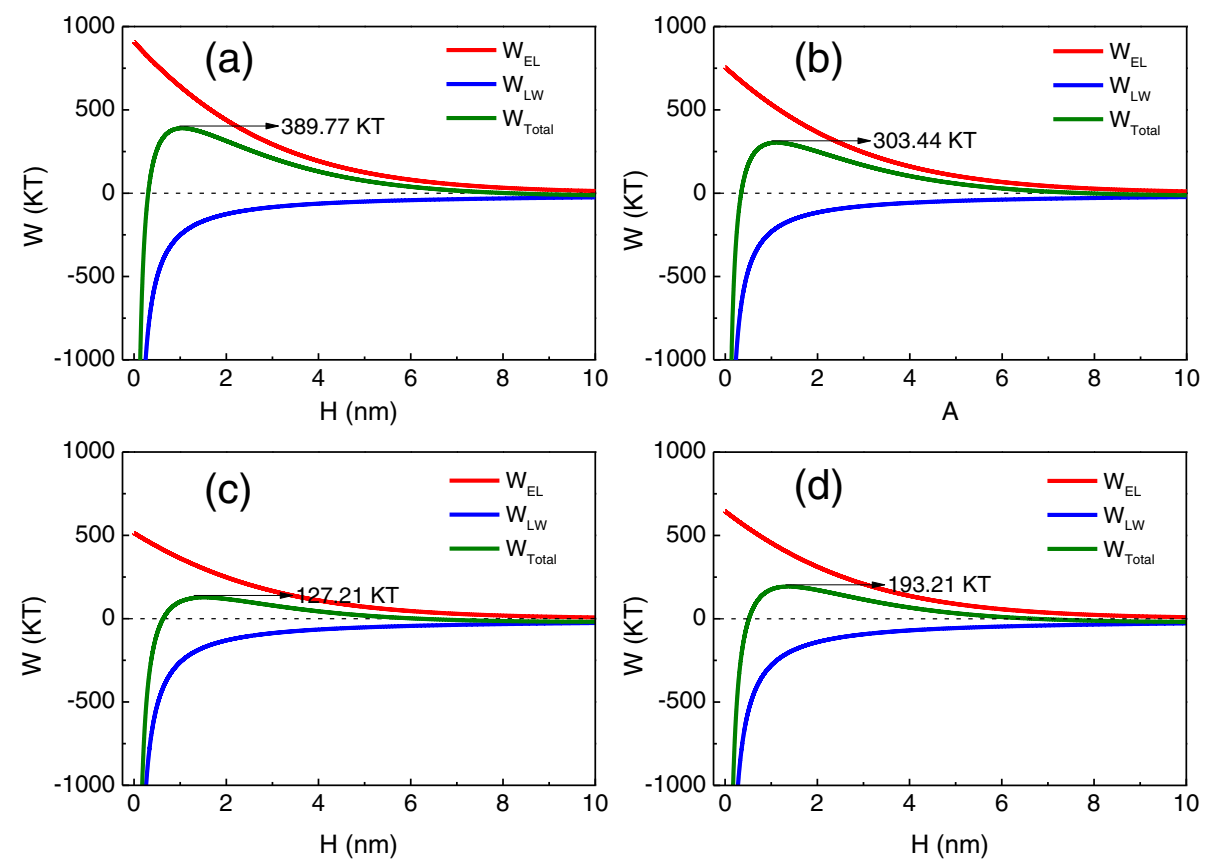

Figure 11 Interaction energy profiles as a function of cells distance at various L-cysteine concentrations (g/l). (a), 0.0; (b), 0.5; (c), 1.0; (d), 1.5 .

not only promoted production of EPS, in particular the secretion of protein, but also stabilized the final confirmation of protein in EPS. Research also noted that the cell surface covered by EPS have been changed by L-cysteine, thus absolute zeta potential decreased with L-cysteine and reached minimum at $1.0 \mathrm{~g} / \mathrm{l}$, which greatly decreased electrostatic repulsion interaction energy based on DLVO theory. Further analysis indicated that total interaction energy barrier decreased from $389.77 \mathrm{KT}$ at $0.0 \mathrm{~g} / \mathrm{l}$ of L-cysteine to 127.21 $\mathrm{kT}$ at $1.0 \mathrm{~g} / \mathrm{l}$. This led to the $R$. faecalis RLD-53 overcome the total interaction energy barrier and flocculate effectively. Therefore, forming stable floc caused by L-cysteine offers great advantages for the realization of enhancing production yield and scale-up application in bio-hydrogen production.

A better understanding the flocculation behaviour of PFB triggered by L-cysteine not only could help the design of subsequent hydrogen production process by flocculation of PFB, but also might favour the further understanding of the bioflocculation mechanism.

\section{Methods}

Bacterium, medium and culture conditions

The photo-hydrogen producer used in this study was Rhodopseudomonas faecalis RLD-53 [42]. Acetate was used as the sole carbon source, and glutamate was used as nitrogen source in the medium for hydrogen production. The culture medium of strain RLD-53 was prepared as described in previous report [42].
The batch culture experiments were carried out in triplicate with $80 \mathrm{ml}$ of the medium in $100 \mathrm{ml}$ sealed reactors and filled with argon to maintain anaerobic conditions [43].The reactors were autoclaved at $121^{\circ} \mathrm{C}$ for $15 \mathrm{~min}$. R. faecalis RLD-53 in the mid-exponential growth phase was inoculated into reactors. The light intensity on the outside surface of the reactors was maintained at $150 \mathrm{~W} /$ $\mathrm{m}^{2}$ by incandescent lamps $(60 \mathrm{~W})$. The reactors were stirred at $120 \mathrm{rpm}$ at constant temperature of $35^{\circ} \mathrm{C}$.

\section{Hydrogen production kinetics}

Modified Gompertz equation has been widely accepted and used to determine the kinetic parameters of hydrogen production [44]. After cumulative hydrogen production curves were obtained over the course of an entire batch experiment, modified Gompertz equation was used to describe the hydrogen production kinetics at different L-cysteine concentrations:

$$
H=H_{\max } \exp \left\{-\exp \left[\frac{R_{\max } e}{H_{\max }}(\lambda-t)+1\right]\right\}
$$

Where $t$ is culture time (h); $H$ is cumulative $\mathrm{H}_{2}$ production (ml/l medium); $H_{\max }$ is maximum cumulative $\mathrm{H}_{2}$ production (ml/l medium); $e=2.71828 ; R_{\max }$ is $\max -$ imum $\mathrm{H}_{2}$ production rate $(\mathrm{ml} / \mathrm{l} / \mathrm{h})$; and $\lambda$ is the lagphase time $(\mathrm{h})$. 


\section{Scanning electron microscope (SEM)}

Surface morphology of the bioflocculation samples was evaluated by a scanning electron microscope [45]. The bioflocculation samples were fixed with $2.5 \%$ glutaraldehyde and left for $1.5 \mathrm{~h}$ in a $4^{\circ} \mathrm{C}$ refrigerator. The samples were gently washed with phosphate buffer solution and then dehydrated by successive passages through $50 \%, 70 \%$, $80 \%, 90 \%$, and $100 \%$ ethanol. Each rinsing and dehydrating step took $10 \mathrm{~min}$. The samples were refreeze dried (Hitachi E-2030, Japan) for $4 \mathrm{~h}$, subsequently coated with gold powder by Sputter Coater (Hitachi E-1010, Japan) and finally attached on to the microscope supports with silver glue. Scanning electron microscope images were taken at $5 \mathrm{kV}$ using an SEM (Hitachi S-3400N, Japan).

\section{X-ray photoelectron spectroscopy (XPS)}

Surface elements concentrations and functional groups on cell surface were determined by the XPS method, which detected the outermost molecular layers (mainly EPS) of the cell surface $(2-5 \mathrm{~nm})$ [46]. After $72 \mathrm{~h}$ cultivation, $R$. faecalis RLD-53 cultured at different L-cysteine concentrations were harvested by centrifugation at $12000 \mathrm{rpm}$ for $10 \mathrm{~min}$ and washed twice with double distilled water. Collected cell samples were placed in a freeze-dryer for about $48 \mathrm{~h}$ (until freeze-dried). XPS was carried out on a PHI5600 equipped with a monochromatic $\mathrm{Al} \mathrm{K \alpha}$ source and data acquisition and processing were conducted using the PC Access ESCA version 7.2A program. The anode voltage and power were $12.5 \mathrm{kV}$ and $250 \mathrm{~W}$, respectively. The pressure in analysis chamber was maintained at $10^{-9}$ Torre during each measurement. All binding energies were referenced to the $\mathrm{C}$ 1s neutral carbon peak at $284.6 \mathrm{eV}$. Spectra were analysed using XPSPeak software (Version 4.1).

\section{Zeta potential and flocculability tests}

The bacterial cells cultured at different L-cysteine concentrations were harvested by centrifugation at 12000 rpm for $10 \mathrm{~min}$ and washed twice with $0.9 \% \mathrm{NaCl}$ solution. The bacterial cells were resuspended in $0.01 \mathrm{~mol} / \mathrm{l}$ $\mathrm{NaCl}$ solution. These cell suspensions were used for the zeta potentials measurement (Nano-ZS, Malvern Co., UK) and flocculability tests. The absorbance of prepared cell suspensions was also measured with a spectrophotometer (Shimadzu UV-2550; Shimadzu, Kyoto, Japan) at $650 \mathrm{~nm}\left(A_{0}\right)$. Thereafter, the cell suspensions were centrifuged at $1000 \mathrm{rpm}$ for $2 \mathrm{~min}$, and the supernatant optical density was measured again at $650 \mathrm{~nm}\left(A_{t}\right)$. Thus, the flocculability of $R$. faecalis RLD-53 value can be calculated using the following equation.

$$
F \%=\left(1-\frac{A_{t}}{A_{0}}\right) \times 100 \%
$$

\section{EPS extraction}

EPS was extracted using cation exchange resin [47] (Dowex Marathon C, 20-50 mesh, sodium form, Fluka 91973). The bacterial cells were collected by centrifugation at $12000 \mathrm{rpm}$ for $10 \mathrm{~min}$. And then the cells were washed twice with $0.9 \% \mathrm{NaCl}$ solution. Subsequently, the cells were re-suspended in $\mathrm{ddH}_{2} \mathrm{O}$ and transferred to an extraction beaker. And then the beaker was added resin $(70 \mathrm{~g} / \mathrm{g}$ VSS) and stirred at $600 \mathrm{rpm}$ for $12 \mathrm{~h}$ at $4^{\circ} \mathrm{C}$. The samples was centrifuged at $12000 \mathrm{~g}$ for $30 \mathrm{~min}$ followed by filtration using a $0.45 \mu \mathrm{m}$ cellulose acetate membrane to remove resin, microorganisms, and residual debris to obtain an EPS sample for further analysis.?>

\section{Fourier transform infrared spectroscopy (FTIR)}

The FTIR spectra of EPS samples were determined using a Fourier transform infrared spectrophotometer (Spectrum One-B, Perkin Elmer, U.S.). The freeze-dried EPS samples were ground with infrared grade $\mathrm{KBr}$ and press into pellets and used for FTIR measurement. For each sample, 350-400 scans were collected over the spectral range of $400-4000 \mathrm{~cm}^{-1}$ at a resolution of $4 \mathrm{~cm}^{-1}$. The protein conformation was analysed from the amide I region [30]. Component peaks were fitted with Gaussian band profiles using the frequencies of the components deduced from the second derivatives.

\section{Interaction energy evaluated by DLVO approach}

Application of the DLVO approach required the surface thermodynamic parameters, which was determined by measuring the contact angles and using the Lifshitz van der Waals acid-base approach [48].

The DLVO interaction energy $\left(W_{\text {Total }}\right)$ between two bacterial cells can be calculated as the sum of the van der Waals $\left(W_{L W}\right)$ and electrostatic $\left(W_{E L}\right)$ interaction energies $[49,50]$ :

$$
W_{\text {Total }}=W_{L W}+W_{E L}
$$

where

$$
\begin{aligned}
& W_{L W}=-\frac{A_{B L B} R}{12 H} \\
& W_{E L}=2 \pi \varepsilon R \psi_{s}{ }^{2} \ln (1+\exp (-\kappa H))
\end{aligned}
$$

Where $A_{B L B}$ is the effective Hamaker constant. $H$ is the separation distance between the cells. $R$ is the cell radius of $R$. faecalis RLD-53, determined by the Malvern Mastersizer 2000 (Malvern Instruments Ltd., UK). $\psi_{s}$ and $\mathrm{K}$ represent the stern potential and inverse of the Debye length respectively, which are related to the electric double layer interaction $W_{E L}$. $\psi_{s}$ could be replaced 
by zeta potential measurement and $\kappa$ can be calculated from different electrolyte concentrations.

\section{Analytical method}

Light intensity was measured at the surface of reactor with solar power meter TENMARS TM-207 (Tenmars Electronics CO., LTD., Taiwan, China). Biogas was sampled from the head space of the photobioreactor by using gastight glass syringes and hydrogen content was determined by using a gas chromatograph (Agilent 4890D, Agilent Technologies, USA). The gas chromatograph column was Alltech Molesieve 5A 80/100. Argon was used as the carrier gas with a flow rate of $30 \mathrm{ml} / \mathrm{min}$. Temperatures of the oven, injection, detector, and filament were $35^{\circ} \mathrm{C}$, $120^{\circ} \mathrm{C}, 120^{\circ} \mathrm{C}, 140^{\circ} \mathrm{C}$, respectively. Residual acetate in culture broth was determined using a second gas chromatograph (Agilent 7890 A, Agilent Technologies, USA) equipped with a flame ionization detector. The liquor samples were firstly centrifuged at 12,000 rpm for $5 \mathrm{~min}$, and filtered through a $0.2 \mu \mathrm{m}$ membrane before free acids were analyzed. The operational temperatures of the injection port, the column and the detector were 220, 190 and $220^{\circ} \mathrm{C}$, respectively. Nitrogen was used as carrier gas at flow rate of $50 \mathrm{ml} / \mathrm{min}$.

Whole-cell nitrogenase activity was assayed by acetylene reduction following the procedure in our previous report [51]. The polysaccharide content in EPS was determined by the anthrone method [52] using glucose as a standard. The protein and humic substance in EPS were measured followed the modified Lowry method [53] using bovine serum albumin and humic acid (Fluka Chemical Corp., USA) as the respective standards. The nucleic acid content was measured by the diphenylamine colorimetric method [54] using fish DNA as the standard. Thiol (SH) and disulfide bond (SS) in EPS were determined using 5-5'-dithio-bis (2-nitrobenzoic acid) (DTNB) according to the method of Ellman [37] and the procedure reported by Kalapathy et al. [55].

\section{Additional files}

Additional file 1: Figure S1. XPS spectra of $R$. faecalis RLD-53 at different concentration of L-cysteine (g/l). (a), 0.0; (b), 0.5; (c), 1.0; (d), 1.5.

Additional file 2: Figure S2. High-resolution fitted $C 1 \mathrm{~s}, \mathrm{O}$ 1s and $\mathrm{N}$ 1s spectra of $R$. faecalis RLD-53 at different concentration of L-cysteine.

Additional file 3: Figure S3. Absolute zeta potential of $R$. faecalis RLD-53 at different concentration of L-cysteine.

\section{Abbreviations}

PFB: Photo-fermentative bacteria; DLVO: Derjaguin-Landau-VerweyOverbeek; EPS: Extracellular polymeric substances; FTIR: Fourier Transform Infrared Spectroscopy; SEM: Scanning electron microscope; XPS: X-ray photoelectron spectroscopy; DTNB: 5-5'-dithio-bis (2-nitrobenzoic acid).

\section{Competing interests}

The authors declare that they have no competing interests.

\section{Authors' contributions}

All authors contributed intellectually via scientific discussions during the work and have read and approved the final manuscript. Guo-Jun Xie designed the study, executed the experimental work, data interpretation and drafted the manuscript. Bing-Feng Liu participated in experimental design and data interpretation, and reviewed the manuscript. De-Feng Xing helped the determination of nitrogenase activity. Nan Jun made a Hypothesis to explain humic substances increase. Ding Jie commented on the manuscript and contributed to the design of the study. Nan-Qi Ren contributed to the design of the study, data interpretation and reviewed the manuscript.

\section{Acknowledgements}

This research was supported by the National Natural Science Foundation of China (No. 51106040 and 51178140), Shanghai Tongji Gao Tingyao Environmental Science \& Development Foundation, China Postdoctoral Science Foundation (No. 2012T50366), Heilongjiang Postdoctoral Financial Assistance (No. LBH-Z11120), Project 51121062 (National Creative Research Groups), 863 Program (No. 2011AA060905), the open Project of State Key Laboratory of Urban Water Resource and Environment, Harbin Institute of Technology (No. HC201212).

Received: 26 November 2012 Accepted: 29 April 2013

Published: 3 May 2013

\section{References}

1. Masset J, Calusinska M, Hamilton C, Hiligsmann S, Joris B, Wilmotte A, Thonart $P$ : Fermentative hydrogen production from glucose and starch using pure strains and artificial co-cultures of Clostridium spp. Biotechnology for Biofuels 2012, 5:35

2. Abreu AA, Karakashev D, Angelidaki I, Sousa DZ, Madalena Alves M: Biohydrogen production from arabinose and glucose using extreme thermophilic anaerobic mixed cultures. Biotechnology for Biofuels 2012, 5:36.

3. McKinlay JB, Harwood CS: Photobiological production of hydrogen gas as a biofuel. Curr Opin Biotechnol 2010, 21:244-251.

4. Gilbert JJ, Ray S, Das D: Hydrogen production using Rhodobacter sphaeroides (OU 001) in a flat panel rocking photobioreactor. Int $J$ Hydrogen Energy 2011, 36:3434-3441.

5. Boran E, Özgür E, Yücel M, Gündüz U, Eroglu I: Biohydrogen production by Rhodobacter capsulatus Hup- mutant in pilot solar tubular photobioreactor. Int J Hydrogen Energy 2012, 37:16437-16445.

6. Adessi A, Torzillo G, Baccetti E, De Philippis R: Sustained outdoor $\mathrm{H}_{2}$ production with Rhodopseudomonas palustris cultures in a $50 \mathrm{~L}$ tubular photobioreactor. Int J Hydrogen Energy 2012, 37:8840-8849.

7. Xie GJ, Liu BF, Guo WQ, Ding J, Xing DF, Nan J, Ren HY, Ren NQ: Feasibility studies on continuous hydrogen production using photo-fermentative sequencing batch reactor. Int J Hydrogen Energy 2012, 37:13689-13695.

8. Tsygankov AA, Fedorov AS, Laurinavichene TV, Gogotov IN, Rao KK, Hall DO: Actual and potential rates of hydrogen photoproduction by continuous culture of the purple non-sulphur bacterium Rhodobacter capsulatus. Appl Microbiol Biotechnol 1998, 49:102-107.

9. Boran E, Ozgur E, van der Burg J, Yucel M, Gunduz U, Eroglu I: Biological hydrogen production by Rhodobacter capsulatus in solar tubular photo bioreactor. Journal of Cleaner Production 2010, 18:S29-S35.

10. Watanabe M, Sasaki K, Nakashimada Y, Kakizono T, Noparatnaraporn N, Nishio N: Growth and flocculation of a marine photosynthetic bacterium Rhodovulum sp. Appl Microbiol Biotechnol 1998, 50:682-691.

11. Watanabe M, Sasaki K, Nakashimada Y, Nishio N: High density cell culture of a marine photosynthetic bacterium Rhodovulum $s p$. with selfflocculated cells. Biotechnol Lett 1998, 20:1113-1117.

12. Liu XM, Sheng GP, Yu HQ: DLVO approach to the flocculability of a photosynthetic $\mathrm{H}_{2}$-producing bacterium, Rhodopseudomonas acidophila. Environ Sci Technol 2007, 41:4620-4625.

13. Sheng GP, Yu HQ, Li XY: Extracellular polymeric substances (EPS) of microbial aggregates in biological wastewater treatment systems: $A$ review. Biotechnol Adv 2010, 28:882-894.

14. Liao BQ, Allen DG, Droppo IG, Leppard GG, Liss SN: Surface properties of sludge and their role in bioflocculation and settleability. Water Res 2001, 35:339-350.

15. Sobeck DC, Higgins MJ: Examination of three theories for mechanisms of cation-induced bioflocculation. Water Res 2002, 36:527-538. 
16. Bardwell JCA, McGovern K, Beckwith J: Identification of a protein required for disulfide bond formation in vivo. Cell 1991, 67:581-589.

17. Doig AJ, Williams DH: Is the hydrophobic effect stabilizing or destabilizing in proteins?: The contribution of disulphide bonds to protein stability. J Mol Biol 1991, 217:389-398.

18. Zhang L, Feng $X$, Zhu N, Chen J: Role of extracellular protein in the formation and stability of aerobic granules. Enzyme Microb Technol 2007, 41:551-557.

19. Higgins MJ, Novak JT: Characterization of exocellular protein and its role in bioflocculation. J Environ Eng-Asce 1997, 123:479-485.

20. Rubio LM, Ludden PW: Maturation of nitrogenase: a biochemical puzzle. $J$ Bacteriol 2005, 187:405-414.

21. Hausinger R, Howard J: Thiol reactivity of the nitrogenase Fe-protein from Azotobacter vinelandii. J Biol Chem 1983, 258:13486-13492.

22. Schrauzer GN, Schlesinger G: Chemical evolution of a nitrogenase model I. Reduction of acetylene and other substrates by a molybdenum-thiol catalyst system. J Am Chem Soc 1970, 92:1808-1809.

23. Adiga P, Sivarama Sastry K, Sarma P: Amino acid interrelationships in cysteine toxicity in Neurospora crassa. J Gen Microbiol 1962, 29:149-155.

24. LiU Y, Fang HHP: Influences of extracellular polymeric substances (EPS) on flocculation, settling, and dewatering of activated sludge. Crit Rev Environ Sci Technol 2003, 33:237-273.

25. Cheng WP, Chi FH: A study of coagulation mechanisms of polyferric sulfate reacting with humic acid using a fluorescence-quenching method. Water Res 2002, 36:4583-4591.

26. Kowalski JM, Parekh RN, Wittrup KD: Secretion efficiency in Saccharomyces cerevisiae of bovine pancreatic trypsin inhibitor mutants lacking disulfide bonds is correlated with thermodynamic stability. Biochemistry 1998, 37:1264-1273.

27. Inan M, Aryasomayajula D, Sinha J, Meagher MM: Enhancement of protein secretion in Pichia pastoris by overexpression of protein disulfide isomerase. Biotechnol Bioeng 2006, 93:771-778.

28. Darby N, Creighton TE: Disulfide bonds in protein folding and stability. Methods Mol Biol 1995, 40:219-252

29. Goldberg ME, Guillou Y: Native disulfide bonds greatly accelerate secondary structure formation in the folding of lysozyme. Protein Sci 1994, 3:883-887

30. Byler DM, Susi $\mathrm{H}$ : Examination of the secondary structure of proteins by deconvolved FTIR spectra. Biopolymers 1986, 25:469-487.

31. Moulin AM, O'Shea SJ, Badley RA, Doyle P, Welland ME: Measuring SurfaceInduced Conformational Changes in Proteins. Langmuir 1999, 15:8776-8779.

32. Roach P, Farrar D, Perry CC: Interpretation of protein adsorption: surfaceinduced conformational changes. J Am Chem Soc 2005, 127:8168-8173.

33. Lundqvist $M$, Sethson I, Jonsson $B H$ : Protein adsorption onto silica nanoparticles: Conformational changes depend on the particles' curvature and the protein stability. Langmuir 2004, 20:10639-10647.

34. Hermansson M: The DLVO theory in microbial adhesion. Colloids Surf $B$ Biointerfaces 1999, 14:105-119.

35. Mill PJ: The Nature of the Interactions between Flocculent Cells in the Flocculation of Saccharomyces cerevisiae. J Gen Microbiol 1964, 35:61-68.

36. Nishihara H, Toraya T, Fukui S: Effect of chemical modification of cell surface components of a brewer's yeast on the floc-forming ability. Arch Microbiol 1977, 115:19-23.

37. Cieśla J, Bieganowski A, Janczarek M, Urbanik Sypniewska T: Determination of the electrokinetic potential of Rhizobium leguminosarum bv trifolii Rt24.2 using Laser Doppler Velocimetry - A methodological study. J Microbiol Methods 2011, 85:199-205

38. Wilson WW, Wade MM, Holman SC, Champlin FR: Status of methods for assessing bacterial cell surface charge properties based on zeta potential measurements. J Microbiol Methods 2001, 43:153-164.

39. Jucker BA, Zehnder AJB, Harms H: Quantification of polymer interactions in bacterial adhesion. Environ Sci Technol 1998, 32:2909-2915.

40. Liu XM, Sheng GP, Luo HW, Zhang F, Yuan SJ, Xu J, Zeng RJ, Wu JG, Yu HQ: Contribution of extracellular polymeric substances (EPS) to the sludge aggregation. Environ Sci Technol 2010, 44:4355-4360.

41. Chrysikopoulos CV, Syngouna VI: Attachment of bacteriophages MS2 and DX174 onto kaolinite and montmorillonite: Extended-DLVO interactions. Colloids Surf B Biointerfaces 2012, 92:74-83
42. Ren NQ, Liu BF, Ding J, Xie GJ: Hydrogen production with $R$. faecalis RLD53 isolated from freshwater pond sludge. Bioresour Technol 2009, 100:484-487.

43. Xie GJ, Liu BF, Ding J, Xing DF, Ren HY, Guo WQ, Ren NQ: Enhanced photo- $\mathrm{H}_{2}$ production by Rhodopseudomonas faecalis RLD-53 immobilization on activated carbon fibers. Biomass Bioenergy 2012, 44:122-129.

44. Xie GJ, Liu B-F, Ding J, Ren H-Y, Xing DF, Ren NQ: Hydrogen production by photo-fermentative bacteria immobilized on fluidized bio-carrier. Int $J$ Hydrogen Energy 2011, 36:13991-13996.

45. Xie GJ, Liu BF, Xing DF, Nan J, Ding J, Ren HY, Guo WQ, Ren NQ: Photohydrogen production by Rhodopseudomonas faecalis RLD-53 immobilized on the surface of modified activated carbon fibers. RsC Advances 2012, 2:2225-2228.

46. Liao BQ, Lin HJ, Langevin SP, Gao WJ, Leppard GG: Effects of temperature and dissolved oxygen on sludge properties and their role in bioflocculation and settling. Water Res 2011, 45:509-520.

47. Chan KY, Xu LC, Fang HHP: Anaerobic Electrochemical Corrosion of Mild Steel in the Presence of Extracellular Polymeric Substances Produced by a Culture Enriched in Sulfate-Reducing Bacteria. Environ Sci Technol 2002, 36:1720-1727.

48. Bayoudh S, Othmane A, Mora L, Ben Ouada H: Assessing bacterial adhesion using DLVO and XDLVO theories and the jet impingement technique. Colloids Surf B Biointerfaces 2009, 73:1-9.

49. Omoike A, Chorover J: Spectroscopic Study of Extracellular Polymeric Substances from Bacillus subtilis: Aqueous Chemistry and Adsorption Effects. Biomacromolecules 2004, 5:1219-1230.

50. Kataoka Y, Kondo T: FT-IR Microscopic Analysis of Changing Cellulose Crystalline Structure during Wood Cell Wall Formation. Macromolecules 1998, 31:760-764

51. Xie GJ, Liu BF, Xing DF, Ding J, Nan J, Ren HY, Guo WQ, Ren NQ: The kinetic characterization of photofermentative bacterium Rhodopseudomonas faecalis RLD-53 and its application for enhancing continuous hydrogen production. Int J Hydrogen Energy 2012, 37:13718-13724.

52. Garidel P: Mid-FTIR-Microspectroscopy of stratum corneum single cells and stratum corneum tissue. PCCP 2002, 4:5671-5677.

53. Frølund B, Griebe T, Nielsen PH: Enzymatic-Activity in the ActivatedSludge Floc Matrix. Appl Microbiol Biotechnol 1995, 43:755-761.

54. Beech I, Hanjagsit L, Kalaji M, Neal AL, Zinkevich V: Chemical and structural characterization of exopolymers produced by Pseudomonas sp NCIMB 2021 in continuous culture. Microbiology 1999, 145:1491-1497.

55. Kalapathy $U$, Hettiarachchy $N$, Rhee K: Effect of drying methods on molecular properties and functionalities of disulfide bond-cleaved soy proteins. J Am Oil Chem Soc 1997, 74:195-199.

\section{doi:10.1186/1754-6834-6-64}

Cite this article as: Xie et al:: Photo-fermentative bacteria aggregation triggered by L-cysteine during hydrogen production. Biotechnology for Biofuels 2013 6:64.

\section{Submit your next manuscript to BioMed Central and take full advantage of:}

- Convenient online submission

- Thorough peer review

- No space constraints or color figure charges

- Immediate publication on acceptance

- Inclusion in PubMed, CAS, Scopus and Google Scholar

- Research which is freely available for redistribution 